\title{
Peningkatan Model Pembelajaran Pengenalan Binatang Melalui Video Animasi
}

\author{
Article Title in English \\ Christy Atika Sari ${ }^{1}$, Eko Hari Rachmawanto ${ }^{2}$, De Rosal Ignatius Moses Setiadi ${ }^{3}$ \\ ${ }^{1,2,3}$ Program Studi Teknik Informatika, Fakultas Ilmu Komputer, Universitas Dian Nuswantoro \\ E-mail: ${ }^{1}$ atika.sari@dsn.dinus.ac.id, ${ }^{2}$ eko.hari@dsn.dinus.ac.id, ${ }^{3}$ moses@dsn.dinus.ac.id
}

\begin{abstract}
Abstrak
Pada makalah ini, telah dipaparkan mengenai cara pemebelajaran bagi anak usia dini. Terdpaat $\mathrm{du}$ acara pembelajaran dalam ranah visual, yaitu pembelajaran visual statis dan dinamis. Mitra pengabdian, dalam hal ini Guru TK PGRI 08 Purowyoso dan siswa anak usia 4-6 tahun sejumlah 45 orang, telah diobservasi dan terbukti bahwa hasil permbelajaran menggunakan video animasi memudahkan guru dalam mengajar, memudahkan siswa dalam belajar, menambah motivasi bekajar, siswa menjadi lebih aktif bertanya dan berani untuk menjelaskan apa yang mereka lihat dalam video tersebut. Dalam pengabdian yang telah dilakukan, digunakan materi pemebelajaran berupa video animasi yang diperkenalkan menggunakan laptop dan handphone serta buku animasi statis. Video dapat menjadi asisten dari guru dalam mengajar dan mempermudah penguasaan pemelajaran aktif bagi siswa.
\end{abstract}

Kata kunci: Video Animasi, Pendidikan, PAUD

\begin{abstract}
In this paper, it has been explained about the way of learning for young children. There were two learning events in the visual realm, namely static and dynamic visual learning. Dedicated partners, in this case Purowyoso PGRI 08 Kindergarten Teachers and 45 4-6 years old students, have been observed and proven that the results of learning using animated videos make it easier for teachers to teach, facilitate students in learning, increase motivation to learn, students become more actively ask questions and dare to explain what they see in the video. In the service that has been done, used learning material in the form of animated videos that were introduced using laptops and mobile phones as well as static animation books. Video can be an assistant of the teacher in teaching and facilitate the mastery of active learning for students.
\end{abstract}

Keywords: 3-5 keywords, workshop, technology, computer

\section{PENDAHULUAN}

Teknik pembejaran pada PAUD merupakan rangkaian dari pengenalan kognitif, afektif dan psikomotorik [1]. Percobaan menggunakan beberapa teknik pembelajaran diharapkan dapat meningkatkan antusias dan rasa percaya diri pada siswa. Dalam makalah ini akan diterapkan teknik belajar visual [2].

Penelitian ini memberikan bukti eksperimental mengenai pemrosesan visual ilustrasi animasi versus statis statis anak-anak berusia 4-6 tahun di buku cerita. Empat puluh empat peserta mendengarkan buku animasi dan statis, keduanya tiga kali, sementara gerakan mata terdaftar dengan pelacak mata. Hasil menguatkan hipotesis bahwa gerak khusus adalah yang menarik perhatian anak-anak sambil melihat ilustrasi. Ilustrasi animasi yang sangat cocok dengan teks panduan cerita anak-anak ke bagian-bagian ilustrasi yang penting untuk memahami cerita [3]. Ini mungkin menjelaskan mengapa buku animasi menghasilkan pemahaman yang lebih baik daripada buku statis. 
Asensio dan Young [4] menegaskan bahwa integrasi video digital tanpa batas dengan alat-alat lain menawarkan kesempatan untuk bereksperimen dengan video sebagai fokus pembelajaran jaringan. Mereka mengembangkan kerangka Tiga I (gambar, interaktivitas dan integrasi) untuk membantu para guru dengan desain pedagogik dan pengembangan streaming video.

Tabel 1 Perbandingan pemahanan nelajar dengan visual maupun teknik gabungan

\begin{tabular}{|c|c|c|}
\hline Gambar & Tnteraktif & Gabungan Gambar dan Interaktif \\
\hline Video lebih menarik & $\begin{array}{c}\text { Siswa idealnya memiliki } \\
\text { kendali }\end{array}$ & $\begin{array}{c}\text { Mengizinkan presentasi } \\
\text { dinamis }\end{array}$ \\
\hline $\begin{array}{c}\text { Mengizinkan saya bekerja di } \\
\text { luar kelas dan menggambarkan } \\
\text { bagaimana teori / teknik dapat } \\
\text { diterapkan dalam kehidupan } \\
\text { nyata }\end{array}$ & $\begin{array}{l}\text { Menyediakan lingkungan } \\
\text { pengajaran yang interaktif }\end{array}$ & Menambahkan nilai ke teks \\
\hline $\begin{array}{l}\text { Orang-orang menerima lebih } \\
\text { banyak informasi ketika } \\
\text { disajikan secara visual } \\
\text { dibandingkan dengan teks dan } \\
\text { suara saja }\end{array}$ & $\begin{array}{l}\text { Kemampuan untuk } \\
\text { mengulang / berhenti }\end{array}$ & $\begin{array}{l}\text { Dukungan untuk mengajar } \\
\text { dan belajar, bukan sebagai } \\
\text { ganti }\end{array}$ \\
\hline $\begin{array}{l}\text { Mampu melihat ahli teknis / } \\
\text { contoh / demonstrasi }\end{array}$ & $\begin{array}{l}\text { Kemampuan untuk } \\
\text { mengulang / berhenti }\end{array}$ & $\begin{array}{l}\text { Gabungan media untuk siswa } \\
\text { yang belajar dari jauh }\end{array}$ \\
\hline $\begin{array}{l}\text { Terlihat bagus-dapat } \\
\text { mendorong pengguna yang }\end{array}$ & $\begin{array}{l}\text { Dapat memilih apa yang } \\
\text { digunakan }\end{array}$ & $\begin{array}{l}\text { Untuk memperluas peserta } \\
\text { dan membahas gaya belajar }\end{array}$ \\
\hline $\begin{array}{c}\text { malas } \\
\text { Itu menarik perhatian, ini baru }\end{array}$ & Dapat memilih apa yang & $\begin{array}{c}\text { yang berbeda } \\
\text { Video dapat bekeria }\end{array}$ \\
\hline & digunakan & berdampingan dengan kuliah \\
\hline Iniadalah cara yang baik untuk & Untuk memberikan & $\begin{array}{l}\text { dan memuji modul siswa } \\
\text { Mampu membagi video }\end{array}$ \\
\hline menyampaikan ide-ide siswa & 'chemistry' pribadi antara & menjadi beberapa bagian dan \\
\hline tanpa perlu menulis & $\begin{array}{l}\text { kuliah dan mahasiswa yang } \\
\text { jauh }\end{array}$ & berhubungan dengan latihan \\
\hline Itu menambah nilai hiburan & Siswa dapat melihat dengan & Integrasi dengan sumber \\
\hline & percaya diri & daya web \\
\hline Gambar dapat dengan cepat & Jumlah pemirsa yang lebih & Dukungan dan umpan balik \\
\hline memberikan informasi & besar dapat dihubungi & siswa dan umpan balik \\
\hline $\begin{array}{c}\text { sedangkan kata-kata bisa lebih } \\
\text { lama }\end{array}$ & & kepada pengajar \\
\hline
\end{tabular}

Dalam makalah ini, telah dilakukan permainan dengan video interaktif yang bersifat mendidik dan menghibur dengan harapan menggunakan sistem seperti itu untuk membandingkan pembelajaran digital murni dan campuran sehubungan dengan perbedaan efektivitas belajar. Selain melakukan eksperimen di mana anak-anak belajar menggunakan video, kami juga melibatkan guru sebagai bagian dari penelitian untuk memungkinkan pengamatan aspek emosional anak-anak.

\section{METODE PELAKSANAAN}

Seorang guru mengajar kelompok siswa pertama tentang jenis binatang menggunakan metode ceramah tradisional dan kemudian siswa mengikuti ujian yang terdiri dari 3 pertanyaan pilihan ganda. Jawaban atas pertanyaan terkait dengan video pembelajaran interaktif. Sekelompok siswa lain hanya menonton materi pembelajaran interaktif kami dan menjawab 3 pertanyaan. Kelompok siswa terakhir memvisualisasikan materi kami bersama dengan instruksi guru ketika dibutuhkan. Kemudian mereka duduk untuk menjawab 3 pertanyaan yang sama. Model pengajaran manual dilakukan oleh guru seperti Gambar 1, sedangkan Gambar 2 memperilhatkan 
siswa yang sedang focus mendengarkan dan melihat video interaktif.

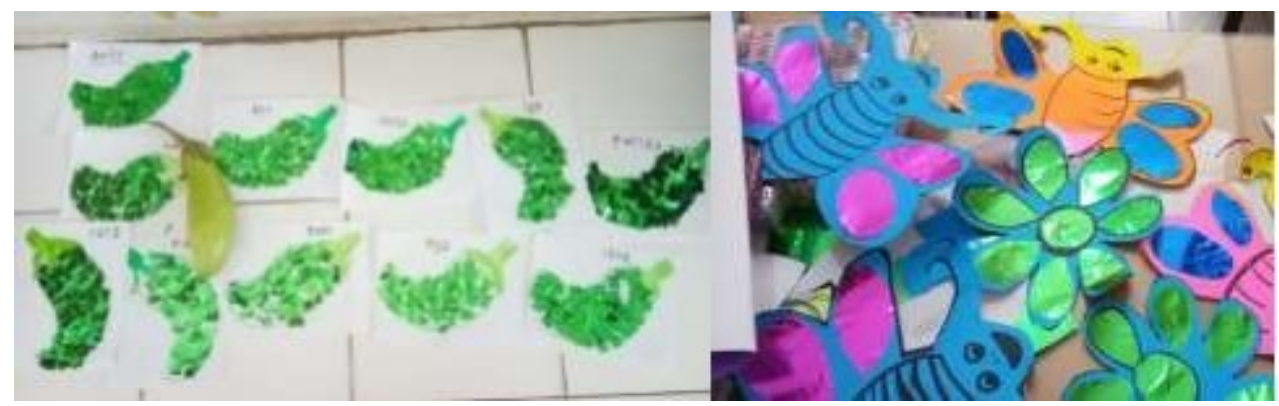

Gambar 1. Media dalam pengenalan buah dan hewan

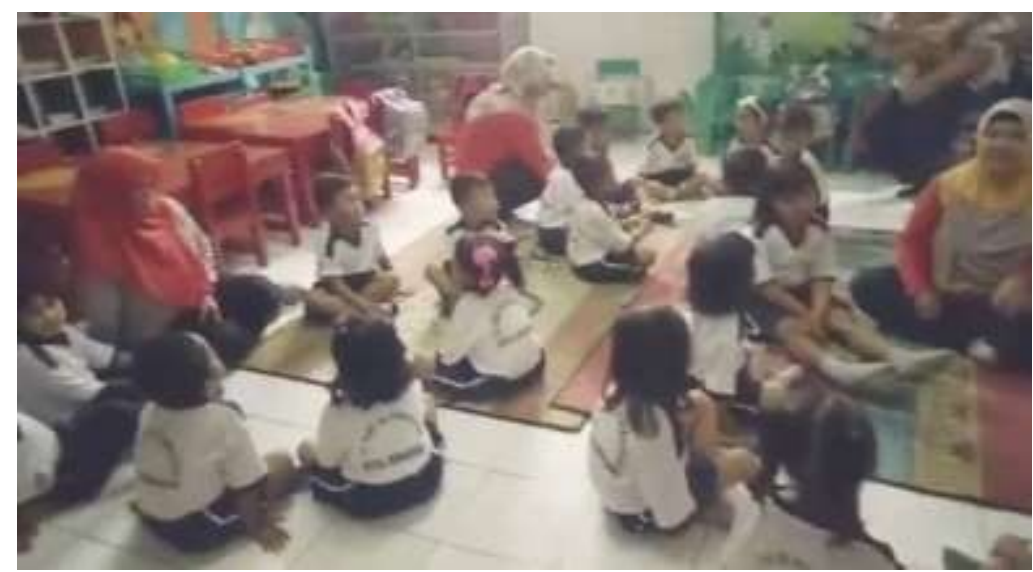

Gambar 2. Hasil KBM secara konvensional oleh guru

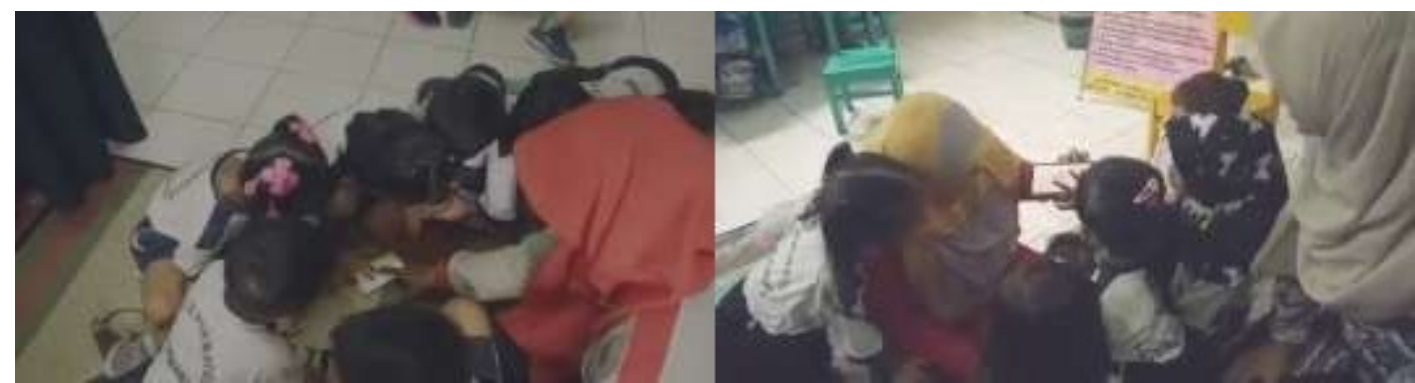

Gambar 3. KBM dengan video interaktif

Dalam pengabdian yang telah dilaksanakan, guru dan tim pengandian saling melakukan evaluasi terhadap hasil belajar siswa. Pada TK PGRI 08 Purwoyoso, terdapat 44 siswa yang diampu oleh 5 orang guru dalam kelas A dan B. pembelajaran dilakukan dengan media handphone dan laptop yang berisi video interaktif.

\section{HASIL DAN PEMBAHASAN}

Pada pelaksaan pengabdian, kami melakukan proses pengajaran melalui media interaktif dengan cara menjelaskan video interaktif pengenalan hewan dan video puzzle hewan. Pada Gambar 4, terdapat rangkuman hasil belajar siswa, dimana siswa dikenalkan jenis dan nama hewan. Siswa harus menebak nama hewan dan bagian tubuh hewan dengan benar. Tim pengabdian membuat 3 buah pertanyaan yang harus dijawab oleh siswa. Pertanyaan antara lain:

(1) Apakah adik suka jika belajar menggunakan video animasi? Jawaban: ya/tidak.

(2) Apakah adik tahu ini jenis hewan apa? (tim menunjuk 3 ekor hewan dalam video), 
jawaban: siswa mampu menyebutkan semua nama hewan yang ditunjukkan tim.

(3) Apakah adik suka jika belajar dikelas menggunakan video pengenalan hewan sperti ini? Jawaban: ya/tidak melihat materi pembelajaran interaktif.

Ketika guru mengetahui jawaban yang diperoleh lebih baik dibandingkan dengan metode pengajaran konvensional, maka guru dapat mengeavaluasi jalannya KBM. Kegiatan menggambar, bernyanyi, menari, menggosok gigi, menempel,mewarnai, dan lainnya tetap penting untuk perkembangan kognitif dan psikomotorik siswa, namun penggunaan video interaktif di rasa perlu di masukkan pada salah satu KBM pada hari tertentu untuk menambah daya ingat dan motivasi belajar siswa.

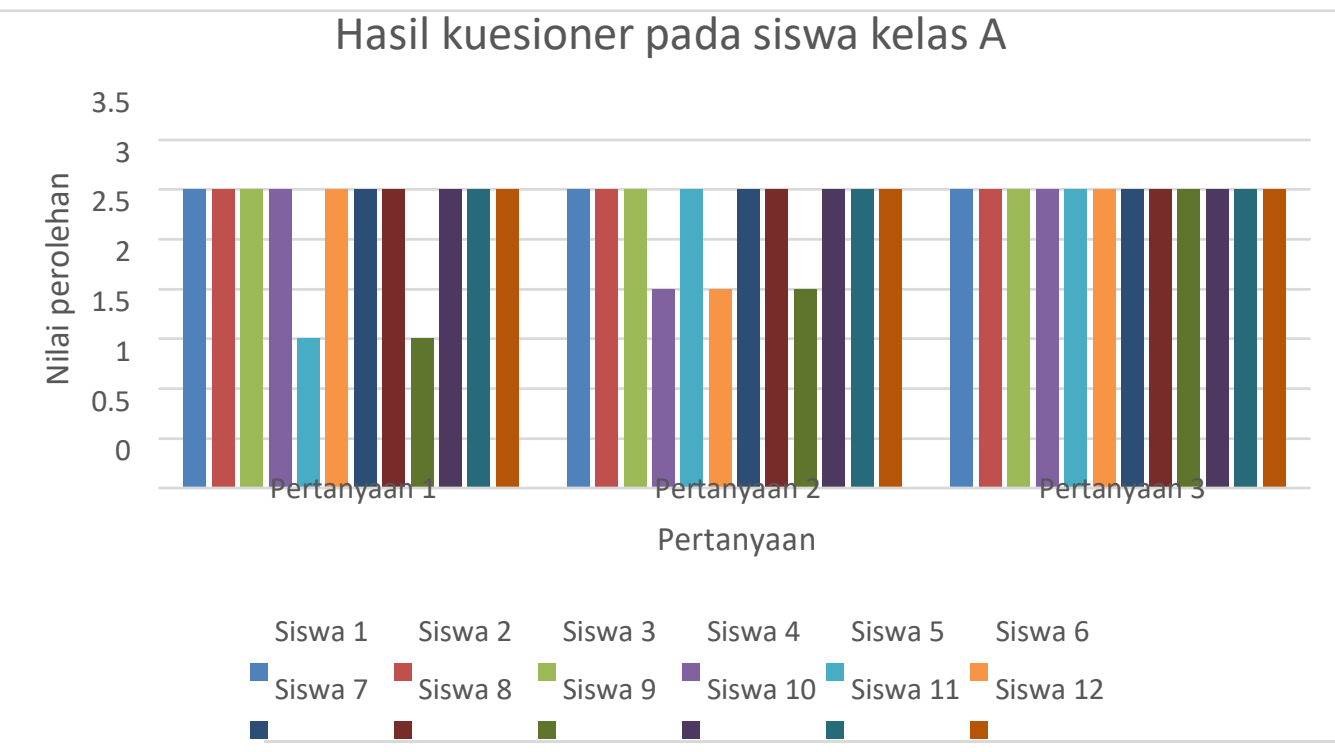

Gambar 4 Hasil kuesioner pada pemahanan materi KBM dengan video interaktif di kelas A

Hasil kuesioner pada siswa kelas B

3.5

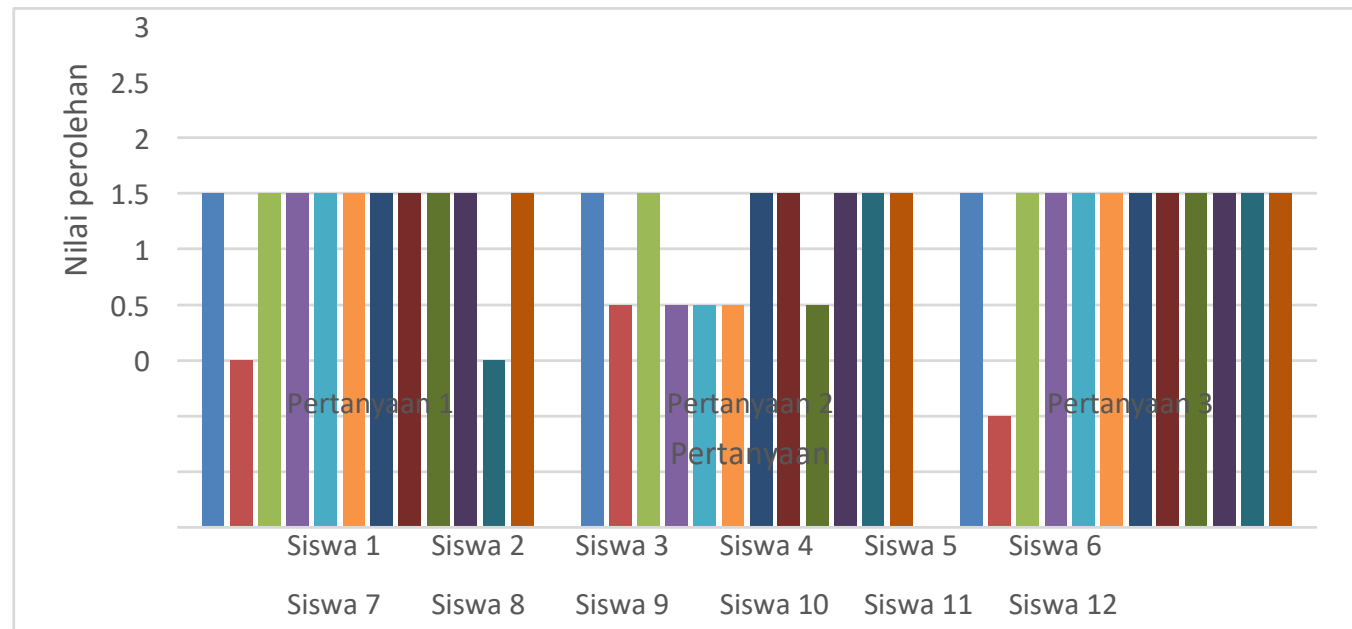

Gambar 5 Hasil kuesioner pada pemahanan materi KBM dengan video interaktif di kelas B

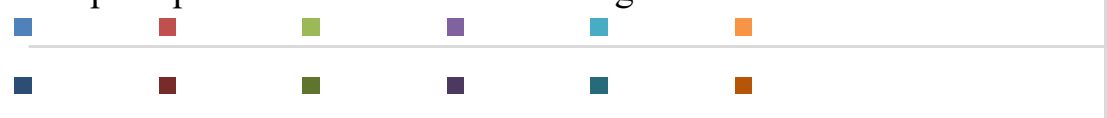


Berdasarkan Gambar 4 dan Gambar 5, tim pengbdi dan guru juga ingin tahu mengenai perasaan siswa yang sangat antusias dan ingin melihat video lebih lanjut sehingga dapat membantu keberhasilan proses KBM. Pada akhir video interaktif, adakan ada suara yang menginformasikan nama dari hewan yang di tebak. Apabila salah, siswa menjadi lebih paham mengenai nama hewan yang benar. Hasil investigasi menggunakan kuesioner menunjukkan bahwa siswa lebih aktif dan antusias dalam belajar. "materi semacam ini sangat membantu siswa karena siswa menjadi aktif, semangat dan tidak bosan", demikian dipaparkan oleh Kepala Sekolah TK PGRI 08 Purwoyoso Semarang, Ibu Soelistyaningrum, S.Pd.

Pada TK ini terdapat 5 orang guru termasuk kepala sekolah yang adalah PNS. 4 guru lain terdiri dari 1 guru PNS, 3 guru swasta yang berpendidikan PAUD sehingga lebih jeli dalam memahami karakter siswa. Ekspresi guru juga sangat antusias, terlebih lagi guru dapat mengenalkan bahwa belajar menggunakan teknologi ternyata sangat menyenangkan. Di sisi lain, guru dapat melatih kemampuan pedagogik dalam menjelaskan konsep hingga materi dasar hewan serta mereview kegiatan kelas dan menyusun menjadi program penelitian tindakan kelas yang akan dilaporkan pada saat rapat DABIN. Gambar 6 sampai Gambar 8 merupakan suasana belajar dan hasil pembelajaran dengan metode visual menggunakan video interaktif.

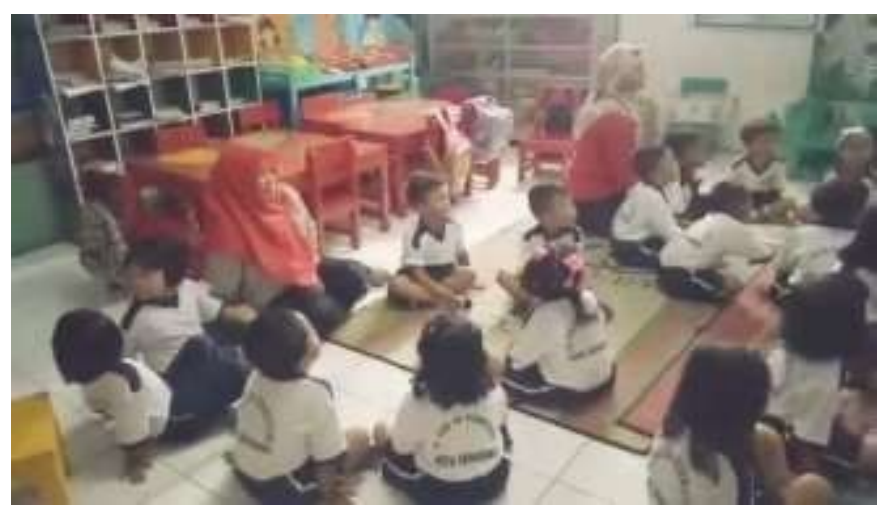

Gambar 6 Siswa sangat antusias belajar

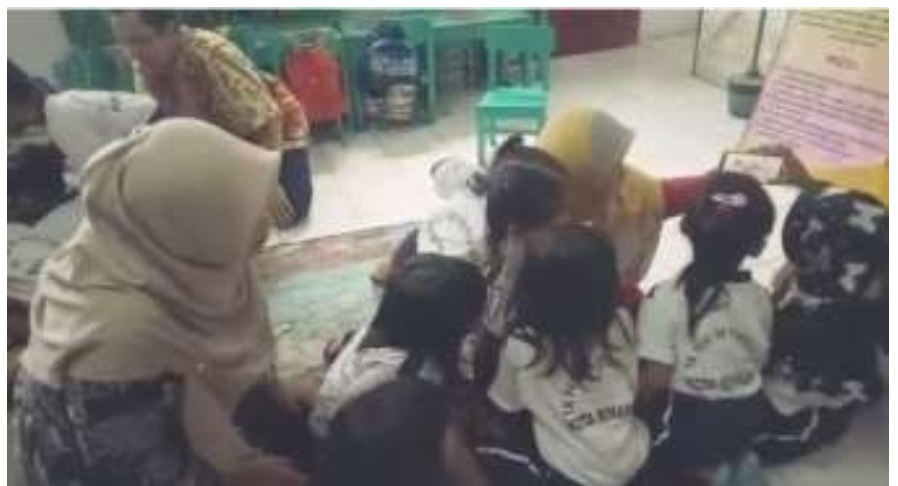

Gambar 7 Siswa sedang berusaha menebak jenis hewan 


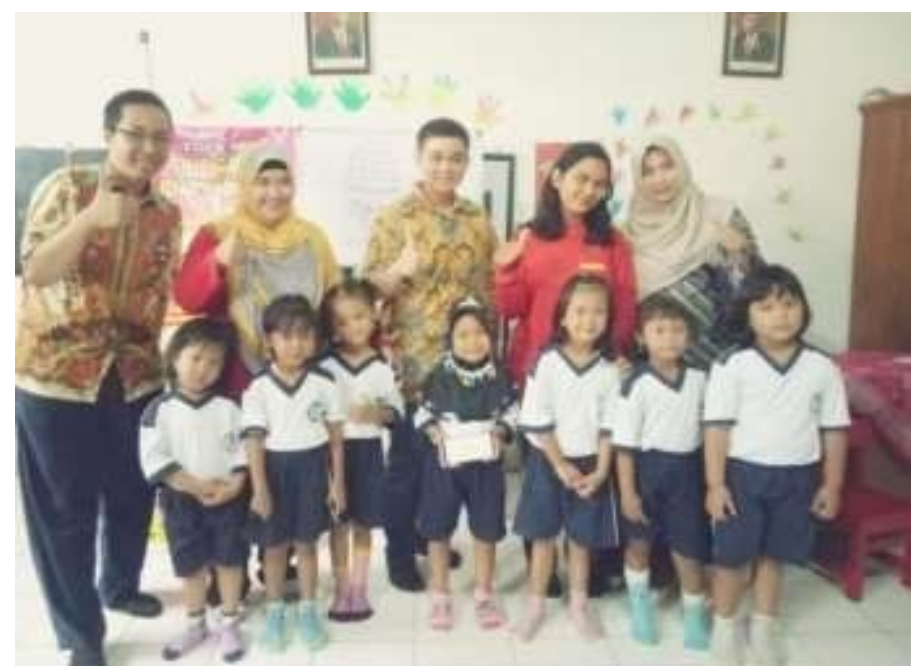

Gambar 8 Foto bersama salah satu kelompok dan guru TK PGRI 08 Purwoyoso

Salah satu kelompok siswa berhak mendapatkan hadiah dari tim pengabdian sebab mampu menjawab seluruh pertanyaan, mampu mneyusun puzzle dan mampu menyebutkan semua nama hewan pada aplikasi.

\section{KESIMPULAN DAN SARAN}

Dalam kegiatan pengabdian ini, siswa maupun guru sangat antusias. Dari hasil kuesioner diketahui bahwa siswa sangat suka dan menjadi lebih mudah paham karena ada rasa semangat dan asyik dalam belajar. Rasa nyaman tentu saja penting, mengingat luaran dari sekolah dalam PAUD adalah pengenalan lingkungan dan rasa bangga dan bahagia terhadap diri sendiri. Menurut Ibu kepala sekolah TK PGRI 08, guru setuju untuk memberikan materi menggunakan teknik visual pada hari jumat dengan kegiatan review materi menggunakan video dalam sesi akhir di hari jumat dengan tujuan siswa menjadi lebih senang dan kembali bersemangat sekolah pada hari senin mendatang.

\section{DAFTAR PUSTAKA}

[1] M. B. Islam, A. Ahmed, M. K. Islam and A. K. Shamsuddin, "Child Education Through Animation: An Experimental Study," International Journal of Computer Graphics \& Animation (IJCGA), vol. 4, no. 4, 2014.

[2] H. Sun, J. Loh and A. C. Roberts, "Motion and Sound in Animated Storybooks for Preschoolers' Visual Attention and Mandarin Language Learning: An Eye-Tracking Study With Bilingual Children," AERA Open, vol. 5, no. 2, pp. 1-19, 2019.

[3] B. Baglama, Y. Yucesoy and A. Yikmis, "Using Animation as a Means of Enhancing Learning of Individuals with Special Needs," TEM Journal, vol. 7, no. 3, pp. 670-677, 2018.

[4] P. Karppinen, "Meaningful Learning with Digital and Online Videos: Theoretical Perspectives," $A A C E$ Journal, vol. 13, no. 3, pp. 233-250, 2005. 